\title{
PENGARUH EKSTRAK LOMPONG (Colocasia esculenta L. Schoot) 30 MENIT PENGUKUSAN TERHADAP AKTIVITAS FAGO SITOSIS DAN KADAR NO (NITRIT OKSIDA) MENCIT BALB/C SEBELUM DAN SESUDAH TERINFEKSI Listeria monocytogenes
}

\author{
Arsela Rindang Sholikhah, Hesti Murwani Rahayuningsih")
}

Program Studi Ilmu Gizi Fakultas Kedokteran Universitas Diponegoro

Jl.Dr.Sutomo No.18, Semarang, Telp (024) 8453708, Email : gizifk@ undip.ac.id

\begin{abstract}
Background: Extract of lompong's leaf and stem was reported to have antimicrobial properties because it contained phytochemicals such as phenols, tannins, saponins, steroids, quinine, trepenoid, glycosides and alkaloids. Steaming was a cooking method that able to maintain the phytochemicals in vegetables.

Objective: To analyze the effect of lompong extract 30 minutes of steaming with $13 \mathrm{mg} / 20 \mathrm{gBW}$ doses towards phagocytosis activity and NO (nitric oxide) level of macrophages in mice Balb/c before and after infected by Listeria monocytogenes

Method:True experimental research with post-test with randomized control group design in 21 male Balb/c mice aged 8-10 weeks were divided randomly into 3 groups with 7 mice each group. K Group (control) mice only received standard feed. P1 group (First treatment) mice was given 30 minutes steamed lompong extract for three days before infected by Listeria monocytogenes. $P 2$ group (Second treatment) mice was given 30 minutes steamed lompong extract for three days after infected by Listeria monocytogenes.

Result:The K group compared to group P1,P2 showed no significant differences. However, P1 group has higher average of phagositosis and NO level than others group.

Conclusion:Lompong extract with 30 minutes of steaming do not show any significant difference to the phagocytic activity and NO level of macrophages for both group, before and after infection.

Keyword: lompong extract, phagocytosis activity, nitric oxide levels
\end{abstract}

\begin{abstract}
ABSTRAK
Latar belakang:Ekstrak daun dan batang lompong (Colocasia esculenta (l.) Schott) dilaporkan memiliki sifat antimikrobial karena mengandung fitokimia seperti fenol, tanin, saponin, streoid, kuinin, trepenoid, glikosida, dan alkaloid. Pengukusan merupakan metode pemasakan yang mampu mempertahankan fitokimia pada sayuran.

Tujuan:Menganalisis pengaruh pemberian ekstrak lompong 30 menit pengukusan dengan dosis 13 mg/20gBB terhadap aktivitas fagositosis dan kadar NO (Nitrit Oksida) makrofag pada mencit Balb/c sebelum dan sesudah terinfeksi Listeria monocytogenes

Metode:Penelitian true experimental dengan post test with randomized control group design pada 21 mencit Balb/c jantan usia 8-10 minggu yang dibagi menjadi 3 kelompok secara acak masing-masing 7 ekor. Kelompok K (Kontrol) mencit hanya mendapatkan pakan standar. Kelompok P1 (Perlakuan satu) mencit diberi ekstrak lompong 30 menit pengukusan selama tiga hari sebelum diinfeksi Listeria monocytogenes. Kelompok P2 (Perlakuan dua) mencit diberi ekstrak lompong 30 menit pengukusan selama tiga hari setelah diinfeksi Listeria monocytogenes.

Hasil: Tidak terdapat perbedaan bermakna pada aktivitas fagositosis dan kadar NO antara kelompok P1,P2 dibandingkan dengan kelompok $K(p>0,05)$. Namun rerata aktivitas fagositosis dan kadar NO kelompok P1 lebih tinggi dibandingkan dengan kelompok $K$ dan $P 2$.

Kesimpulan:Pemberian ekstrak lompong dengan 30 menit pengukusan pada mencit selama 3 hari tidak memiliki perbedaan yang signifikan terhadap aktivitas fagositosis dan kadar NO makrofag, baik sebelum infeksi Listeria monocytogenes maupun setelah infeksi Listeria monocytogenes.
\end{abstract}

Kata kunci:Ekstrak lompong, aktivitas fagositosis, kadar NO

\section{PENDAHULUAN}

Lompong memiliki nama ilmiah Colocasia esculenta (l.) Schott atau yang lebih dikenal dengan tanaman lompong merupakan salah satu tanaman jenis umbi-umbian. Lompong mudah ditemui di sekitar lingkungan yang lembab seperti sepanjang sungai dan tepi danau. Tanaman ini dianggap sebagai tanaman yang agresif karena pertumbuhannya yang cepat. Masyarakat biasa memanfaatkan tanaman ini untuk diolah daun dan batangnya menjadi sayur. ${ }^{1,2}$ Selain dikonsumsi sebagai sayur, daun lompong juga sering dimanfaatkan sebagai penurun panas oleh masyarakat. $^{3}$

Berdasarkan penelitian pendahulu, lompong dilaporkan memiliki kandungan vitamin $\mathrm{C}$, oksalat yang tinggi, dan fitokimia seperti fenol, tanin, saponin, streoid, kuinin, trepenoid, glikosida, dan alkaloid. Semua bagian lompong, baik daun, batang, dan umbi dilaporkan memiliki sifat 
antimikrobial, antioksidan, dan antikanker. Sifat antimikrobial ekstrak daun lompong ditunjukkan dengan efektivitasnya melawan bakteri patogen penyebab penyakit seperti tifoid, pneumonia, infeksi saluran kemih, dan diare. ${ }^{4-6}$ Sifat antioksidan yang dimiliki lompong mampu meningkatkan efektivitas hepatoprotektif dan antihepatotoksik. Bagian batang menunjukkan aktivitas antioksidan tertinggi dibandingkan pada daun dan umbi. ${ }^{5,7}$

Sayuran biasanya dikonsumsi oleh masyarakat Indonesia dalam bentuk lalapan ataupun melalui proses pemasakan terlebih dahulu. Pemasakan merupakan salah satu proses pengolahan menggunakan panas. Salah satu proses pengolahan panas yang biasa digunakan untuk mengolah sayuran adalah pengukusan. ${ }^{8}$ Beberapa penelitian menunjukkan bahwa pengukusan lebih baik dibandingkan dengan perebusan dan penumisan dalam hal mempertahankan fitokimia dan aktivitas antioksidan pada sayuran..$^{9-11}$ Pemanasan ternyata memiliki peran yang penting dalam meningkatkan aktivitas antioksidan senyawa polifenol dan flavonoid. Aktivitas antioksidan akan naik dengan pemanasan pada $100^{\circ} \mathrm{C}$ selama $20-30$ menit. $^{12}$

Senyawa yang berperan sebagai antioksidan pada lompong adalah flavonoid dan alkaloid. Alkaloid berperan dalam peningkatan respon imun. Mekanisme flavonoid dan alkaloid sebagai imunomodulator dengan meningkatkan aktivitas IL-2 (interleukin 2) dan proliferasi limfosit. Sel Th1 (T helper 1) yang teraktivasi akan mempengaruhi SMAF (Specific Macrofag Arming Factor), yaitu molekul-molekul termasuk IFN $\gamma$ (interferon gamma) yang dapat mengaktifkan makrofag. Jika terdapat antigen yang masuk ke tubuh, misalnya bakteri, maka limfosit $\mathrm{T}$ dan makrofag saling bekerja sama untuk membunuh bakteri tersebut. Makrofag akan memfagosit bakteri dan limfosit $\mathrm{T}$ berdiferensiasi menjadi $\mathrm{CD} 4^{+}$dan $\mathrm{CD} 8^{+}$. Sel $\mathrm{CD} 4^{+}$ berdiferensiasi menjadi Th1 yang kemudian menghasilkan sitokin IFN $\gamma$ dan TNF $\alpha$ serta memacu sel Natural Killer. Sel $\mathrm{CD}^{+}$pun menghasilkan sitokin IFN $\gamma$. Sitokin tersebut akan mengaktifkan makrofag untuk menghasilkan senyawa salah satunya nitrit oksida yang berguna membunuh bakteri. ${ }^{13,14}$ Infeksi dalam tubuh manusia bisa disebabkan karena bakteri, virus maupun jamur. Listeria monocytogenes adalah bakteri yang biasa digunakan untuk memperlajari penyakit infeksi. ${ }^{15}$ Bakteri ini mampu menginduksi respon imun seluler yang dilakukan oleh makrofag dengan proses $T$-cell mediated immunity. ${ }^{16}$
Tumbuhan talas diduga berpotensi sebagai imunomodulator karena kandungan kimia yang ada didalamnya, sehingga untuk memperoleh kandungan kimia tersebut maka diperlukan penyarian zat-zat aktif dari bagian tumbuhan talas tersebut yaitu ekstraksi. Penyarian zat-zat aktif tumbuhan dengan metode ekstraksi dapat dilakukan dengan beberapa cara, yaitu maserasi, perlokasi, refluks, sokletasi, digesti, infus, dan dekok. Banyaknya jumlah senyawa aktif yang diperoleh dapat dipengaruhi oleh pemilihan metode ekstraksi. Metode ekstraksi sokletasi adalah metode yang tepat karena menghasilkan jumlah senyawa aktif yang banyak. Hal ini dikarenakan dalam prosesnya digunakan panas yang sesuai dengan titik didih pelarut untuk mempercepat kelarutan senyawa aktif dalam suatu bahan tersebut. ${ }^{17,18}$

Berdasarkan uraian di atas peneliti tertarik pada tanaman ini terkait manfaatnya terhadap kesehatan, khususnya pengaruh terhadap respon imun. Respon imun tubuh dapat dilihat dari aktivitas fagositosis dan kadar NO (Nitrit Oksida) makrofag sebelum atau setelah infeksi. Peneliti ingin menganalisis bahwa ekstrak sayur lompong yang sebelumnya diolah dengan 30 menit pengukusan mampu meningkatkan aktivitas fagositosis makrofag dan kadar NO makrofag. Perlakuan berupa pemberian ekstrak lompong 30 menit pengukusan dibagi menjadi dua kelompok perlakuan, yaitu kelompok perlakuan pertama pemberian ekstrak diberikan sebelum mencit diinduksi Listeria monocytogenes dan kelompok perlakuan kedua pemberian ekstrak diberikan setelah mencit diinduksi Listeria monocytogenes. Pemberian ekstrak lompong sebelum diinduksi bakteri dimaksudkan sebagai tindakan preventif sedangkan pemberian ekstrak lompong setelah diinduksi bakteri dimaksudkan sebagai tindakan kuratif.

\section{METODE PENELITIAN}

Penelitian dilakukan di Laboratorium Parasitologi Fakultas Kedokteran Universitas Diponogero. Ruang lingkup keilmuan penelitian ini yaitu teknologi pangan, imunologi gizi, dan gizi biomedik. Jenis penelitian ini merupakan penelitian true experimental dengan post test with randomized control group design. Sampel dari penelitian ini adalah mencit Balb/c jantan yang diberikan perlakuan berupa pemberian ekstrak lompong (Colocasia esculenta $l$. schoot) 30 menit pengukusansebelum dan sesudah diinduksi Listeria monocytogenes.

Sampel diambil dari mencit yang secara genetic sifatnya sama, maka pengambilan sampel 
dilakukan secara random. Pengelompokan sampel dilakukan secara acak dan dilakukan penimbangan mencit sebelum dan sesudah perlakuan. Hal ini dilakukan untuk menghindari bias karena faktor umur dan berat badan dimana kriteria sampel yang diambil yaitu mencit jantan galur balb/c yang dalam keadaan sehat, memiliki berat badan 20-30 gram dan umur 8-10 minggu. Mencit diadaptasikan terlebih dahulu selama 1 minggu sebelum diberi perlakuan. Mencit diberi makan dan minum secara ad libithum selama dalam pemeliharaan. Mencit yang telah mengalami adaptasi, kemudian dibagi menjadi 3 kelompok secara acak yang masingmasing 7 ekor yaitu kelompok K (Kontrol), P1 (Perlakuan satu) dan P2 (Perlakuan dua).

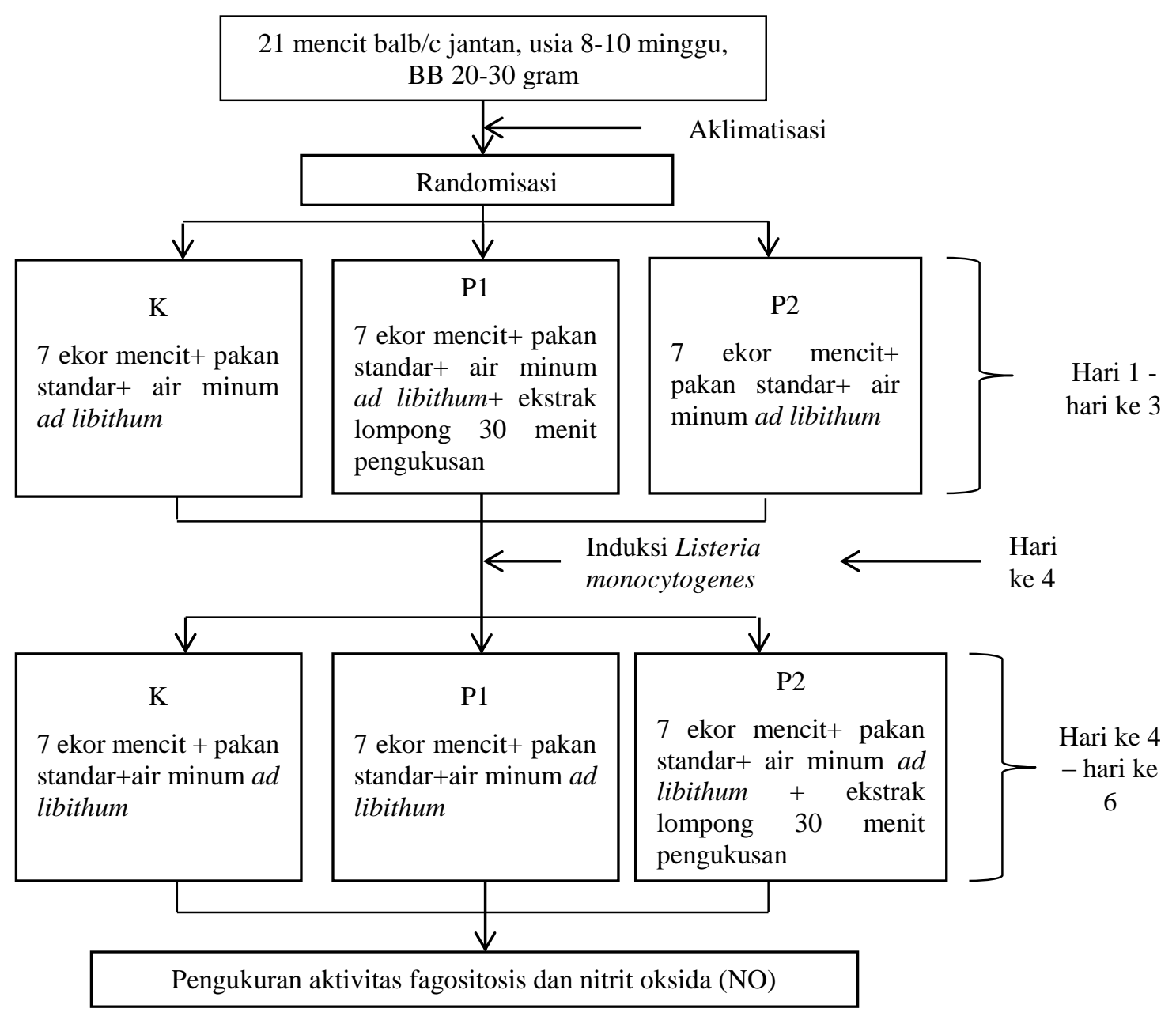

\section{Gambar 1. Alur Kerja Penelitian}

Kelompok pertama yaitu kelompok $\mathrm{K}$ sebagai pembanding, dimana mencit hanya mendapatkan pakan standar. Kelompok P1 adalah kelompok perlakuan dimana mencit diberi ekstrak lompong 30 menit pengukusan dengan dosis 13 $\mathrm{mg} / 20 \mathrm{gBB}$ sebelum diinduksi Listeria monocytogenes. Kelompok P2 adalah mencit diberi ekstrak lompong 30 menit pengukusan dengan dosis $13 \mathrm{mg} / 20 \mathrm{gBB}$ setelah diinduksi Listeria monocytogenes.

Variabel bebas dalam penelitian ini adalah pemberian ekstrak lompong (Colocasia esculenta $L$. Schoot) 30 menit pengukusan dengan dosis 13 $\mathrm{mg} / 20 \mathrm{gBB}$ dan induksi bakteri Listeria monocytogenes dengan dosis $1 \times 10^{5} \mathrm{CFU}$. Variabel terikat dalam penelitian ini adalah aktivitas fagositosis dan kadar NO (Nitrit Oksida). Galur mencit hewan coba, jenis kelamin, umur mencit, pakan mencit, kandang, sistem perkandangan dan waktu penginduksian bakteri Listeria monocytogenes menjadi variabel terkontrol pada penelitian ini.

Data yang dikumpulkan yaitu aktivitas fagositosis dan kadar NO. Kemampuan fagositosis makrofag dinilai menggunakan partikel latex bead yang dinyatakan dalam indeks fagositosis, sedangkan kadar NO makrofag diukur menggunakan reagen Griess dan diukur 
absorbansinya pada $550 \mathrm{~nm}$ menggunakan automated microplate reader (ELISA reader). Data yang telah didapatkan kemudian diolah dengan komputer. Analisis data digunakan untuk menganalisis perbedaan aktivitas fagositosis dan kadar NO pada kelompok K dengan kelompok P1 dan P2. Analisis data diawali dengan uji kenormalan data dengan uji Shapiro-Wilk. Uji beda aktivitas fagositosis dan kadar NO antara kelompok perlakuan menggunakan independent t-test pada data berdistribusi normal dan uji Mann Whitney pada data berdistribusi tidak normal.

\section{HASIL DAN PEMBAHASAN}

Keseluruhan sampel memenuhi syarat penelitian. Total sampel berjumlah 21 ekor mencit $\mathrm{Balb} / \mathrm{c}$ jantan berusia 8-10 minggu dengan berat badan 20-30 gram yang diperoleh dari laboratorium Biologi Fakultas MIPA Unnes. Populasi sampel kemudian dibagi secara random sampling menjadi 3 kelompok yaitu P1, P2 dan K yang masing-masing berjumlah 7 ekor.
Kemampuan fagositosis sel makrofag peritoneum mencit diukur dan dinyatakan dengan indeks fagositosis. Kadar NO diukur absorbansinya menggunakan automated microplate reader (ELISA reader) dan dinyatakan dengan $\mu \mathrm{M}$. Berdasarkan uji normalitas data, data kemampuan fagositosis makrofag berdistribusi normal sedangkan data kadar NO makrofag berdistribusi tidak normal. Sehingga data kadar NO diupayakan memiliki distribusi normal dengan cara ditransformasi. Namun setelah dilakukan upaya transformasi data masih berdistribusi tidak normal.

Berdasarkan hasil uji beda, data aktivitas fagositosis tidak menunjukkan perbedaan bermakna antara kelompok perlakuan dibandingkan dengan kelompok kontrol. Hasil uji beda data kadar NO juga tidak menunjukkan adanya perbedaan bermakna antara kelompok perlakuan dibandingkan dengan kelompok kontrol. Walaupun data aktivitas fagositosis dan kadar NO tidak bermakna secara statistik, namun nilai rerata menunjukkan adanya perbedaan yang dapat dilihat pada tabel 1 .

Tabel 1. Nilai rerata indeks fagositosis makrofag dan Kadar NO

\begin{tabular}{cccc}
\hline \multirow{2}{*}{ Kelompok } & \multirow{2}{*}{$\mathrm{n}$} & \multicolumn{2}{c}{ Rerata \pm sb } \\
\cline { 3 - 4 } & 7 & $3,07 \pm 0,72$ & Kadar NO \\
\hline P1 & 7 & $2,5 \pm 0,29$ & $106,8 \pm 74,4$ \\
P2 & 7 & $2,43 \pm 0,23$ & $94,7 \pm 43,1$ \\
K & & & $106,29 \pm 54,3$ \\
\hline
\end{tabular}

Indeks fagositosis makrofag pada kelompok sebelum diinfeksi memiliki rerata lebih tinggi dibandingkan kelompok setelah diinfeksi dan kelompok K. Kelompok K memiliki rerata jumlah frekuensi latex beads terfagosit lebih rendah diantara kelompok lainnya.

Pemberian ekstrak lompong 30 menit pengukusan belum efektif dalam meningkatkan aktivitas fagositosis. Hal ini bisa disebabkan oleh beberapa faktor. Faktor pertama yang bisa mempengaruhi yaitu dosis. Dosis yang diberikan belum efektif dalam meningkatkan kemampuan fagositosis. Hal tersebut ditunjukkan dengan adanya perbedaan rerata indeks fagositosis antara kelompok sebelum diinfeksi dan kelompok kontrol. Semakin banyak jumlah partikel lateks intrasel menunjukkan semakin tinggi kemampuan fagositosis makrofag. Indeks fagositosis kelompok sebelum diinfeksi lebih tinggi dibandingkan dengan kelompok kontrol. Hal ini menunjukkan bahwa kelompok sebelum diinfeksi memiliki kemampuan fagositosis makrofag lebih baik.

Kadar NO makrofag pada kelompok sebelum diinfeksi memiliki rerata lebih tinggi dibanding kelompok kontrol. Kelompok setelah diinfeksi memiliki rerata kadar NO lebih rendah diantara kelompok lainnya. Hal ini bisa disebabkan oleh kandungan flavonoid pada ekstrak lompong 30 menit pengukusan. Senyawa flavonoid selain mempunyai efek imunostimulan juga memiliki efek imunosupresan. Salah satu senyawa flavonoid yang bersifat imunosupresan yaitu genistein. Genistein bersifat imunosupresan dengan cara menghambat pembentukan NO dan induksi iNOS pada makrofag mencit. ${ }^{19}$ Selain itu dosis pemberian ekstrak lompong 30 menit pengukusan juga belum efektif dalam meningkatkan produksi NO.

Kelompok perlakuan sebelum diinfeksi memiliki nilai rerata indeks fagositosis dan kadar NO yang lebih tinggi dibandingkan dengan kelompok setelah diinfeksi. Hal ini menunjukkan bahwa pemberian ekstrak lompong 30 menit pengukusan sebagai tindakan preventif lebih baik dibandingkan dengan pemberian ekstrak lompong 30 menit pengukusan sebagai tindakan kuratif.

Berdasarkan uji kuantitatif, ekstrak lompong 30 menit pengukusan mengandung fenol 0,219\%, tanin $0,292 \%$ dan flavonoid $0,106 \%$. Kandungan flavonoid pada lompong tersebut dipengaruhi oleh jenis lompong dan pembudidayaannya. Lompong 
yang ditanam di lahan yang kering terbukti mengandung fenol yang tinggi. ${ }^{20} \mathrm{Hal}$ ini yang memungkinkan pemberian ekstrak lompong 30 menit pengukusan belum efektif dalam meningkatkan kemampuan fagositosis dan kadar NO makrofag karena jenis lompong yang digunakan adalah jenis lompong yang mengandung sedikit fenol.

Tabel 2. Hasil Uji Kuantitatif Ekstrak Lompong

\begin{tabular}{cccc}
\hline \multirow{2}{*}{ Ekstrak } & \multicolumn{3}{c}{ Hasil Analisa } \\
\cline { 2 - 4 } & Fenol (\%) & Tanin (\%) & Flavonoid (\%) \\
\hline Mentah $^{21}$ & 0,198 & 0,261 & 0,088 \\
Pengukusan 30 menit & 0,219 & 0,293 & 0,105 \\
Pengukusan 45 menit $^{22}$ & 0,222 & 0,310 & 0,140 \\
\hline
\end{tabular}

Selain itu proses pengukusan juga berpengaruh terhadap kadar fitokimia pada ekstrak sayur lompong. Sayur lompong yang dikukus selama 30 menit secara kuantitatif memiliki kadar fenol, tanin, dan flavonoid lebih tinggi dibandingkan dengan sayur lompong yang mentah. Namun sayur lompong yang dikukus selama 30 menit mengandung fenol, tanin, dan flavonoid sedikit lebih rendah dibandingkan dengan sayur lompong yang dikukus selama 45 menit. Hal ini menunjukkan bahwa proses pemasakan dengan cara dikukus mampu meningkatkan kadar fitokimia didalamnya.

Kandungan fitokimia ekstrak lompong yang dikukus lebih tinggi dibandingkan dengan ekstrak lompong mentah bisa disebabkan oleh serat-serat yang terdapat pada sayur lompong menjadi lebih lunak saat proses pengukusan. Hal ini diduga menyebabkan serat-serat yang lebih lunak memudahkan komponen bioaktif yang terdapat pada ekstrak lompong lebih mudah larut pada pelarutnya.

Kandungan ekstrak lompong dengan 45 menit pengukusan yang lebih tinggi juga berpengaruh terhadap aktivitas fagositosis dan kadar NO pada kelompok sebelum diinfeksi. Hal ini menunjukkan bahwa lamanya pengukusan akan mempengaruhi kandungan fitokimia pada ekstrak lompong serta mempengaruhi peningkatan aktivitas fagositosis dan kadar NO makrofag. ${ }^{22}$

\section{SIMPULAN}

Pemberian ekstrak lompong dengan 30 menit pengukusan pada mencit selama 3 hari tidak memiliki perbedaan yang signifikan terhadap aktivitas fagositosis dan kadar NO makrofag secara statistik, baik sebelum infeksi Listeria monocytogenes maupun setelah infeksi Listeria monocytogenes. Hal ini mungkin dikarenakan pemberian ekstrak lompong yang kurang lama yaitu hanya 3 hari dan dosis ekstrak yang kurang optimal.

\section{SARAN}

Durasi pemberian ekstrak lompong perlu diperpanjang, untuk dapat memberikan pengaruh yang signifikan terhadap respon imun. Pengujian dosis bertingkat untuk penelitian selanjutnya diperlukan agar mendapatkan dosis yang lebih efektif.

\section{DAFTAR PUSTAKA}

1. Gomez-Beloz A, Rivero T. An Edible Aroid of the Warao. Ethnobot. Res. 2006;4:103-11.

2. Matthews PJ, Agoo EMG, Madulid DA, Tandang D. Ethnobotany and Ecology of Wild Taro ( Colocasia esculenta ) in the Philippines: Implications for Domestication and Dispersal. Senri Ethnol. 2012;78:307-40.

3. Husin PH, Pontianak K, Usman FH, Yusro F, Tavita GE, Sisillia L, et al. Identifikasi Jenis - Jenis Tumbuhan Berkhasiat Obat di Jalan Parit H. Husin 2 Kecamatan Pontianak Tenggara. 2007;1-12.

4. Mcewan R. Anti-Nutritional Constituent Of Colocasia Esculenta ( Amadumbe ) A Traditional Crop Food In Kwazulu-Natal [Ph.D Thesis]. University of Zululand; 2008.

5. Wei LS, Wee W, Siong JYF, Syamsumir DF. Antimicrobial, antioxidant, anticancer property and chemical composition of different parts (corm, stem and leave) of Colocasia esculenta extract. Sect. DDD. 2011;24(3):1-8.

6. Dhanraj N, Kadam MS, Patil KN, Mane VS. Phytochemical screening and Antibacterial Activity of Western Region wild leaf Colocasia esculenta. Int. Res. J. Biol. Sci. 2013;2(10):18-21.

7. Patil BR, Ageely HM. Antihepatotoxic Activity Of Colocasia esculenta Leaf Juice. Int. J. Adv. Bioteknol. Res. 2011;2(2):296-304.

8. Aisyah Y, Rasdiansyah, Muhaimin. Pengaruh Pemanasan Terhadap Aktivitas Antioksidan pada Beberapa Jenis Sayuran. Teknol. dan Ind. Pertan. Indones. 2014;6(2):2-7.

9. Lemos MA, Aliyu MMM, Kynoch G, Joseph LR, Hungerford G. Effect of cooking on the levels of bioactive compounds in Purple Majesty Potato. Insid. Food Symp. Belgium: InsideFood Symposium; 2013. p. 1-6. 
10. Porter Y. Antioxidant properties of green broccoli and purple-sprouting broccoli under different cooking conditions. Biosci. Horizons. 2012;5:1-11.

11. Saikia S, Mahanta CL. Effect of Steaming, Boiling and Microwave Cooking on The Total Phenolics, Flavonoids and Antioxidant Properties of Different Vegetable of Assam, India. Int. J. Food Nutr. Sci. 2013;2(3).

12. Santoso U, Setyaningsih E, Cahyanto MN. Pengaruh Pemanasan pada Aktivitas Antioksidan Ekstrak Etanol Beberapa Varietas Ubi Jalar. Angitech. 2006;26(4):163-8.

13. Ukhrowi U. Pengaruh Pemberian Ekstrak Etanol Umbi Bidara Upas (Merremia mammosa) terhadap Fagositosis Makrofag dan Produksi Nitrit Oksida (NO) Makrofag [Thesis]. Univeristas Diponegoro; 2011.

14. Abbas, Lichtmann, Pillai. Cellular and Molecular Immunology. 6th ed. Philadelphia: Elsevier Saunders; 2007. p. 358-60.

15. Munasir Z. Respons Imun Terhadap Infeksi Bakteri. Sari Pediatr. 2001;2(4):193-7.

16. Sulistyo B. Kemampuan Fagositosis Makrofag Mencit Balb / C Yang Diberi Diet Omega-3 Dan Diinfeksi Listeria Monocytogenes [Skripsi]. Universitas Diponegoro; 2008.

17. Istiqomah. Perbandingan Metode Ekstraksi Maserasi Dan Sokletasi Terhadap Kadar Piperin Buah Cabe Jawa (Piperis retrofracti fructus) [Skripsi]. [Jakarta]: UIN Syarif Hidayatullah; 2013.
18. Sinambela AN. Uji Fitokimia Ekstrak Daun Ranti (Solanum nigrum L.) yang Berpotensi sebagai Imunostimulan [Skripsi]. [Medan]: Universitas Negeri Medan; 2012.

19. Middleton E, Kandaswami C, Theoharides TC. The Effects of Plant Flavonoids on Mammalian Cells : Implications for Inflammation , Heart Disease , and Cancer. Pharmacol. Rev. 2000;52(4):673-751.

20. Gonçalves RF, Silva AMS, Silva AM, Valentão P, Ferreres F, Gil-Izquierdo A, et al. Influence of taro (Colocasia esculenta L. Shott) growth conditions on the phenolic composition and biological properties. Food Chem. [Internet]. 2013 Dec 15 [cited 2015 Jul 6];141(4):3480-5. Available from: http://www.ncbi.nlm.nih.gov/pubmed/23993510

21. Sulistiani RP. Pengaruh Ekstrak Lompong Mentah (Colocasia Esculenta L. Schoot) Terhadap Aktivitas Fagositosis dan Kadar NO (NitritOksida) Mencit Balb/c Sebelum dan Sesudah Terinfeksi Listeria monocytogenes [Draft]. [Semarang]: Universitas Diponegoro; 2015

22. Mubayinah. Pengaruh Ekstrak Lompong (Colocasia esculenta L. Schoot) 30 menit Pengukusan Terhadap Aktivitas Fagositosis dan Kadar NO (NitritOksida) Mencit Balb/c Sebelum dan Sesudah Terinfeksi Listeria monocytogenes [Draft]. [Semarang]: Universitas Diponegoro; 2015 